Польченко Ольга Викторовна, Банщикова Татьяна Николаевна

\title{
УЧЕТ В ОБРАЗОВАТЕЛЬНОМ ПРОЦЕССЕ ВУЗА ОСОБЕННОСТЕЙ АККУЛЬТУРАЦИИ ИНОСТРАННЫХ И РОССИЙСКИХ ИНОГОРОДНИХ СТУДЕНТОВ ${ }^{1}$
}

В статье рассматриваются особенности пережсивания процесса аккультурации иностранными обучаючимися и российскими иногородними студентами. Установлено, что в прочессе учеб́ иностранные студенты руководствуются мотивами избегания; воспринимают действия, обраценные к ним как вражсебные; чувствуют стеснетие; руководствуются установками, что их права как представителей другой страны уцемлены. Студенты из ближнего зарубежья менее остро пережсивают процессы аккультурации и легко приспосабливаются к особенностям новой страны, к учебному прочессу. Нногородние русские студенты переживают прочесс аккультурации безболезненно, однако у студентов отдельных национальностей, проживаюицх в республиках Северо-Кавказского федерального округа, выражен показатель аккультурационного стресса - тоска по дому.

Ключевые слова: аккультурация, сочиокультурное пространство, студенты, иногородние студенты, иностранные студенты, учебный процесс.

\section{Olga Polchenko, Tatyana Banschikova \\ SPECIFICS OF ACCULTURATION OF FOREIGN AND RUSSIAN NONRESIDENT} STUDENTS IN THE EDUCATIONAL PROCESS OF THE UNIVERSITY

The specifics of the experience of the process of acculturation by foreign students and Russian nonresident students are considered. It has been established that in the process of studying foreign students are guided by the motives of avoidance; perceive actions addressed to them as hostile; feel constraint; guided by the principles that their rights, as representatives of another country, are violated. Students from neighboring countries are less acutely experiencing the processes of acculturation and easily adapt to the peculiarities of the new country, to the educational process. Nonresident Russian students experience the process of acculturation painlessly, but among students of certain nationalities living in the republics of the North Caucasus Federal District, there is an indicator of acculturation stress - homesickness.

Key words: acculturation, sociocultural space, students, nonresident students, foreign students, educational process.

Bведение / Introduction. Ситуация поступления в вуз для студентов любой страны сопровождается рядом изменений, к которым необходимо адаптироваться: изменения условий жизни, условий обучения; новая роль студента, иные принципы и нормы взаимодействия с суббъектами образовательной процесса и др. Процесс адаптации иностранных студентов и студентов из регионов России с выраженными национальными традициями связан с более серьезными проблемами: преодоление языковых барьеров, приспособление к условиям жизни в иной культуре с ее религиозными, национальными особенностями, ритуалами, традициями, ценностями и нормами. Процесс культурных контактов, взаимодействие представителей разных культур обусловливает необходимость обращения к понятию аккультурация.

Аккультурация - это одновременно и процесс, и результат взаимного влияния разных культур, при котором представители одной культуры перенимают нормы, ценности и традиции другой [3]. Принято выделять основные стратегии аккультурации: ассимиляция; сепарация; маргинализация; интеграция. Учеными (Д. Берри, Я. Путинга, М. Сегалл и П. Дазен) было установлено, что в процессе взаимодействия культуры вступают в сложные отношения, и это приводит как к

Работа выполнена при поддержке РФФИ, проект № 17-06-00804 «Осознанная саморегуляция и совладающее поведение в условиях адаптации студентов к новой социокультурной среде: общие закономерности и кросс-культурные различия». 
успешной адаптации, так и к психосоматическим расстройствам, ощущениям депривации в новой среде, путанице в ценностных ориентациях и ролевом поведении местного населения. Термин «аккультурационный стресс» определяется как «негативные последствия контакта двух самобытных культурных групп, что зачастую приводит к снижению физиологического, психологического и социального благополучия и непроизвольной борьбе в адаптации к новой культуре» [2].

Несмотря на большое количество исследований по проблеме аккультурации (Ю. В. Арутюнян, К. Д. Гарибян, И. А. Кузьмин, Н. М. Лебедева, Т. Г. Стефаненко Ю. Хабермас, А. Щюц и др.), остаются недостаточно изученными этнические особенности переживания аккультурационного стресса, определяющие успешность / неуспешность адаптации иностранных и иногородних студентов к условиям обучения в вузе.

Цель исследования - выявить особенности переживания процесса аккультурации, в зависимости от этнической принадлежности обучающихся, сформулировать предложения по организации образовательного процесса в вузе с учетом особенностей аккультурации обучающихся.

Maтериалы и методы/ materials and methods. Были использованы следующие методики исследования:

1. Шкала аккультурационного стресса иностранных студентов Дайа С. Сандху, Бадиола С. Асрабади [5].

2. Опросник для измерения аккультурационной установки, разработанный (адаптированный) по методике Дж. Берри [4].

В исследовании приняли участие 260 студентов в возрасте от 18 до 25 лет. Выборка представлена респондентами, принадлежащими к большому количеству этнических групп (более 20 этносов), поэтому условно была разделена на группы: русские студенты (Ру), студенты арабских стран (Ар), студенты Юго-Восточной Азии (узбеки, таджики - Аз), африканские студенты (Аф), студенты из республик Северного Кавказа (Кз) (таблица 1).

Таблица 1

Количество участников исследования

\begin{tabular}{|l|c|}
\hline \multicolumn{1}{|c|}{ Этническая принадлежность респондентов } & Общее кол-во участников \\
\hline Русские студенты & 46 \\
\hline Студенты арабских стран & 22 \\
\hline Студенты Юго-Восточной Азии - узбеки & 67 \\
\hline Студенты Юго-Восточной Азии - таджики & 30 \\
\hline Африканские студенты & 67 \\
\hline Студенты из республик Северного Кавказа & 28 \\
\hline Всего & 260 \\
\hline
\end{tabular}

Результаты и обсуждении / Results and discussion. Согласно полученным данным (таблица 2), имеются значимые различия в переживании аккультурационного стресса между исследуемыми группами $(\mathrm{p}=0,0000)$.

Таблицุа 2

Показатели переживания аккультурационного стресса

\begin{tabular}{|l|c|c|c|c|c|c|c|}
\hline \multicolumn{1}{|c|}{ Показатели аккультурации } & Ру & Ар & $\mathbf{y}_{\mathbf{3}}$ & $\mathbf{K 3}$ & Тд & Аф & ANOVA \\
\hline ОУ аккультурац. стресса & 1,7 & 2,4 & 2,2 & 1,7 & 2,5 & 2,6 & 0,000 \\
\hline Воспр. дискриминация & 1,6 & 2,4 & 2,2 & 1,7 & 2,5 & 2,8 & 0,000 \\
\hline Тоска по дому & 2,5 & 3,1 & 3,1 & 2,7 & 3,0 & 2,9 & 0,058 \\
\hline
\end{tabular}




\begin{tabular}{|l|c|c|c|c|c|c|c|}
\hline \multicolumn{1}{|c|}{ Показатели аккультурации } & $\mathbf{P y}$ & $\mathbf{A p}$ & $\mathbf{y}_{\mathbf{3}}$ & $\mathbf{K} 3$ & Тд & Aф & ANOVA \\
\hline Воспр. враждебность & 1,4 & 2,5 & 1,9 & 1,5 & 2,2 & 2,4 & 0,000 \\
\hline Страх & 1,4 & 2,3 & 1,8 & 1,3 & 2,4 & 2,4 & 0,000 \\
\hline Культурный шок & 2,0 & 2,3 & 2,5 & 1,7 & 2,7 & 2,5 & 0,000 \\
\hline Вина & 1,5 & 2,4 & 1,8 & 1,4 & 2,4 & 2,4 & 0,000 \\
\hline Неспецифические проблемы & 1,5 & 2,3 & 2,1 & 1,6 & 2,3 & 2,6 & 0,000 \\
\hline
\end{tabular}

Высокие показатели общего уровня (ОУ) аккультационного стресса наблюдается у студентов из Африки и студентов-таджиков. У данных студентов выше, чем у других, показатели «воспринимаемая дискриминация», «страх», «культурный шок», «неспецифические проблемы». Эти главные составляющие аккультурационного стресса свидетельствуют не только о его наличии, но и о прогрессирующем его состоянии. Объяснить это можно тем, что, кроме биологической адаптации (поясно-временной и климатические условия проживания в России), иностранные обучающиеся испытывают нагрузку, связанную с социально-психологической адаптацией (новый вид деятельности - учеба в вузе, взаимодействие с представителями иных культур), адаптацией к социально-экономическим и социально-бытовым условиям (проживание в общежитии, языковые барьеры и др.) Все это, естественно, требует наличия больших физических и психических ресурсов, усиленной мобилизации для быстрого и эффективного решения возникающих задач. В силу этих обстоятельств у студентов проявляются неблагоприятные признаки как психологического характера: беспокойство, волнение, усталость, тревога, страх, - так и педагогического: затруднения в выполнении учебных задач, снижение мотивации обучения и успеваемости.

Следует отметить и такую особенность: студенты арабы, таджики и африканские студенты наиболее остро переживают «воспринимаемую дискриминацию». Именно "воспринимаемую». Так, любой акцент в оценке поведения, внешнего вида, знаний, обращение к национальной принадлежности (без отрицательного контекста) рассматривается ими как форма враждебного действия, дискриминация. Эта группа студентов имеет высокие значения показателя «вина». Они испытывают чувство вины из-за того, что оставили родных без своего внимания, что в новых условиях им приходится вести другой образ жизни.

Иногородние студенты славянских национальностей и российские студенты из республик Северного Кавказа не испытывают проблем в аккультурации. Относительно выражен показатель «культурный шок» у русских студентов, приехавших на обучение из сельской местности, небольших поселков.

У всех студентов без исключения показатель «тоска по дому» имеет самые выраженные значения, что вполне объяснимо.

На следующем этапе исследования были выявлены основные стратегии аккультурации иностранных студентов (таблица 3 ).

Таблица 3

Стратегии аккультурации иностранных обучающихся

\begin{tabular}{|l|c|c|c|c|c|}
\hline \multicolumn{1}{|c|}{ Стратегии аккультурации } & Ар & $\mathbf{У}_{\mathbf{3}}$ & Тд & Аф & p \\
\hline Ассимиляция & 3,8 & 4,1 & 3,7 & 3,4 & 0,0008 \\
\hline Интеграция & 4,3 & 4,6 & 4,4 & 4,1 & 0,0425 \\
\hline Сепарация & 3,7 & 3,3 & 3,0 & 3,4 & 0,2103 \\
\hline Маргинализация & 3,6 & 3,1 & 2,9 & 3,0 & 0,0652 \\
\hline
\end{tabular}


Полученные результаты позволяют сделать следующие выводы. Из всех представленных групп только узбекские студенты в наибольшей степени готовы принять установки и ценности новой для себя культуры, в определенной степени готовы отказаться от норм и ценностей своей культуры (ассимиляция, интеграция). Это в первую очередь относится к студентам, которые после окончания вуза планируют остаться жить и работать в России.

Стратегии сепарации и маргинализации наиболее выражены у араб́ских студентов. Эти студенты в наибольшей степени не адаптированы к новым социальным условиям, они стремятся сохраниться в рамках своей культуры, используют любую возможность говорить на родном языке, восстановить, насколько это возможно, атрибутику прежнего образа жизни. Вместе с тем они осознают зависимость своего положения, ощущают одиночество, враждебность окружающего мира. Отрицать чужую культуру при сохранении своих этнических особенностей в условиях новой культуры, достаточно сложно, что сопровождается неблагоприятным психологическим состоянием адаптируемой группы.

Преподавателям необходимо знать этнические и психологические особенности иностранных студентов. Так, по данным наших исследований [1], студентов из Африки отличает повышенная тревожность, внешне проявляемая открытость при внутренней «закрытости», прагматичность. Преподавателям не рекомендуется использовать во взаимодействии с африканскими студентами демократический стиль общения, необходимо акцентировать внимание на развитие навыков дисциплинированности, самоорганизации.

Арабские студенты более открыты, чем африканские, при условии установления дружеских отношений. Вместе с тем они недисциплинированны, легко включаются в конфликты. Ocновное внимание во взаимодействии с такими обучающимися необходимо уделять деликатности, спокойствию, развивать навыки самодисциплины.

Студенты из Юго-Восточной Азии (таджики, узбеки) строго следят за своей репутацией, мотивированны на то, чтобы получить возможность остаться жить и работать в России, поэтому стараются соблюдать все правила, спокойно переносят перемены, открыто обсуждают проблемы. Преподавателю необходимо более широко использовать самостоятельные виды работ, задавать много вопросов на размышление, использовать техники морально-этической мотивации.

Несомненно, что социокультурные и психологические факторы оказывают существенное влияние на результаты обучения, но не меньшее значение имеют факторы качества преподаваемого материала, организация процесса обучения, профессиональная компетентность преподавателя. Активная реализация образовательных программ на английском языке, разработка комплексов УМКД на английском языке, повышение квалификации преподавателей в области языковой культуры, оптимальное взаимодействие между подразделениями и сотрудниками, координирующими работу с иностранными студентами, организация эффективного взаимодействия между сотрудниками вуза и студентами, которые являются представителями разных культур - это условия, которые будут способствовать адаптации и позитивной аккультурации иностранных студентов.

Заключение / Conclusion. Настоящее исследование показало, что имеется определенная специфика в переживании аккультурационного стресса иностранными студентами и иногородними российскими студентами. Так, адаптация африканских и таджикских студентов протекает тяжелее, чем у студентов других этнических групп. Иногородние русские студенты и студенты из республик СКФО переживают аккультурационный стресс безболезненно, однако у студентов отдельных национальностей, проживающих на территории РФ, данный показатель все же несколько завышен. Территориально они, иногородние российские студенты разных национальностей, не столь отдалены от своих общностей, дома, с детства зачастую включены в совместную жизнь с русскими ребятами, переживают аккультурационный стресс сильнее иногородних русских ребят, но не так остро, как иностранные. 
Образовательные программы на английском языке будут способствовать снижению уровня стресса, связанного с языковым барьером, и позволят иностранным студентам в большей степени сосредоточиться на содержании изучаемых дисциплин.

\section{ЛИТЕРАТУРА И ИНТЕРНЕТ-РЕСУРСЫ}

1. Банщикова Т. Н., Соколовский М. Л. Особенности взаимосвязи показателей осознанной саморегуляции и параметров совладающего поведения у российских и зарубежных студентов в условиях аккультурации // Образование личности, АНО «Центр научно-практических разработок и экспертиз в об̆ласти образования» (АНО «ЦНПРО»), Москва, 2017, 4, 114 - 121- Русский. URL: http://www.oljournal.ru/about.html

2. Резников Е. Н. Психологические особенности адаптации иностранных студентов в российских вузах // Вестник РУДН, серия Психология и педагогика. 2010. № 1. С. 6-13.

3. Ушканова Р. Д. Логико-семантический анализ аккультурации // Вестник Северо-Восточного федерального университета им. М. К. Аммосова. 2010. № 1. Т. 7. С. 149-153.

4. Berry J. W. [и др.]. Acculturation Attitudes in Plural Societies // Applied Psychology. 1989. № 2 (38). P. $185-206$

5. Sandhu D., Asrabadi B. Development of an Acculturative Stress Scale for International Students: Preliminary Findings // Psychological reports. 1994. (75). P. 435-448.

\section{REFERENCES AND INTERNET RESOURCES}

1. Banshhikova T. N., Sokolovskij M. L. Osobennosti vzaimosvyazi pokazatelej osoznannoj samoregulyacii i parametrov sovladayushhego povedeniya u rossijskix i zarubezhny' $\mathrm{x}$ studentov $\mathrm{v}$ usloviyax akkul turacii (Features of interrelation of indicators of conscious self-regulation and parameters of coping behavior at the Russian and foreign students in the conditions of acculturation) // Obrazovanie lichnosti, ANO «Centr nauchnoprakticheskix razrabotok i e' kspertiz v oblasti obrazovaniya» (ANO «CzNPRO»), Moskva, 2017, 4, 114-121- Russkij / http://www.ol-journal.ru/about.html

2. Reznikov E. N. Psixologicheskie osobennosti adaptacii inostranny'x studentov v rossijskix vuzax (Psychological features of adaptation of foreign students in Russian universities) // Vestnik RUDN, seriya Psixologiya i pedagogika. 2010. № 1. S. 6-13.

3. Ushkanova R. D. Logiko-semanticheskij analiz akkul' turacii (Logical-semantic analysis of acculturation) // Vestnik Severo-Vostochnogo federal 'nogo universiteta im. M. K. Ammosova. 2010. № 1. T. 7. S. 149-153.

4. Berry J. W. [и др.]. Acculturation Attitudes in Plural Societies // Applied Psychology. 1989. № 2 (38). P. $185-206$.

5. Sandhu D., Asrabadi B. Development of an Acculturative Stress Scale for International Students: Preliminary Findings // Psychological reports. 1994. (75). P. 435-448.

\section{СВЕДЕНИЯ ОБ АВТОРАХ}

Польченко Ольга Викторовна, психолог научно-образовательного центра психологического сопровождения личностно-профессионального развития Института образования и социальных наук СКФУ. E-mail: polchenko-olga@yandex.ru

Банцикова Татьяна Николаевна, кандидат психологических наук, доцент, руководитель научно-образовательного центра психологического сопровождения личностно-профессионального развития Института образования и социальных наук СКФУ. E-mail: sevkav@mail.ru

\section{INFORMATION ABOUT AUTHORS}

Olga Polchenko, psychologist of the scientific and educational center for psychological support of personal and professional development of the Institute of Education and Social Sciences, NCFU. E-mail: polchenkoolga@yandex.ru

Tat'yana Banshchikova, candidate of psychological sciences, assistant professor, Head of the Scientific and Educational Center for Psychological Support of Personal and Professional Development of the Institute of Education and Social Sciences, NCFU. E-mail: sevkav@mail.ru 